\title{
Die taal as katedraal: Driepas van T.T. Cloete
}

\author{
Anna van Jaarsveld \& Tom Gouws \\ Departement Afrikaans \\ Universiteit van die Noord-Weste \\ MMABATHO
}

\begin{abstract}
Language as cathedral: Driepas of T.T. Cloete

In the compilation of Driepas the poet T.T. Cloete intended to build a cathedral in language. In this article the structural characteristics of the Gothic cathedral, specifically those of the Chartres cathedral, are examined to determine possible structural correlations between the edifice and the poetic artefact. The structural links between the cathedral of Chartres and the poems in Driepas were mainly ascertained by implementing the analogv of Cloete's bountiful usage of enumeration and his meticulous attention to detailed arrangement. This aspect has previously been overlooked by most critics of Driepas.
\end{abstract}

dankie dat tot eer van God 'n duiselende katedraal met lyding gebou is

("wrede praal": Driepas, p. 81)

\section{Die konsep van die katedraal as leesstrategie}

In hierdie artikel word gepoog om moontlike strukturele parallelle in die samestelling van die eerste afdelings van Driepas van T.T. Cloete en die Wesfront van die Chartres-katedraal aan te toon. As motivering vir hierdie werkwyse en keuse van 'n leesstrategie geld die volgende aspekte:

* Die struktuur van die Chartres-katedraal kom baie duidelik ooreen met dié van die bundel - 'n gegewe wat deur die numering bewys en deur die inhoud ondersteun word. Hierdie aanname word bevestig deur die parallelle in die bundel en die struktuur van die Wesfasade van die Chartres-katedraal.

* Die Chartres-katedraal is die enigste Middeleeuse katedraal in Europa wat hierdie deurlopende ooreenkomste vertoon. 
* Ook is die Chartres-katedraal die enigste katedraal wat in Driepas self genoem word.

In die bespreking word gekonsentreer op die Wesfasade omdat dié fasade die hoofaansig is en toegang tot die katedraal verleen. Gevolglik het dit groter en onmiddellike oortuigingskrag as die volledige strukturele en inhoudelike parallelle met die Wesfasade die grootste klem in die artikel dra ondat hierdie werkwyse as't ware toegang tot die res van die bundelstruktuur verleen. Deur die samestelling van die eerste bundelafdeling met die werklike katedraalaansig in verband te bring word die leser van die artikel vertroud gemaak met 'n leeswyse wat hy dan self kan toepas om die bundel verder te ontsluit en te ontgin.

\section{Middeleeuse argitektuur en die oordra van geestelike waarhede}

Binne die Calvinistiese geloofsraam word die oorsprong van die mens volgens Genesis 1:26 gesien as ' $n$ wilsdaad of -besluit van die Skeppergod om Homself in 'n sigbare gestalte op aarde te laat verteenwoordig. Daardeur wou Hy in die mens 'n soort verlengstuk van Homself vind. Volgens 1 Korintiërs 6:19 word dit egter meer: die mens se liggaam word woonplek vir God. As 'beeld' van God kan dieselfde neiging tot selfekspressie by die mens verwag word. Die eerste vorm daarvan word gevind in die voortplanting van die mens, wat noodwendig sou oorgaan tot die oprigting van 'n woonplek om die gesin te huisves, wat weer sou lei na die grootskaalse oprigting van "saamhoortplekke" ("Il versamelnes", Cloete, 1989:160).

Daar kan aanvaar word dat die kunsbeoefening van die mens ook aangewend sou word om sy woonplek - as metaforiese uitbreiding van sy liggaam - te versier en 'n atmosfeer te skep waarin hy persoonlik tuis kan voel. Hierdie bewoonbare strukture word só ingeklee dat 'n mens selfs sou kon sê dat dit die beskouing van die inwoner weerspieël. Veral in die mens se konstrukte van sy geloofsoortuiginge word aan bepaalde konsepte simbolies in argitektuur beslag gegee. Vanaf Moses se tabernakel tot by Salomo se tempel, vanaf die Middeleeuse katedrale tot by hedendaagse kerke, vind die mens in die argitektuur van sy aanbiddingsplek 'n kreatiewe uitbeelding van sy hoogste mistieke belewing, sowel as van sy aardsgerigtheid.

Tradisioneel is die boustyl van Middeleeuse katedrale ryk aan simboliek. Die blomme en ander loof wat op fresko's uitgebeeld word, is dié van plante wat in die omgewing van die katedraal aan die bouers bekend was. Die Bybelse konings en die Christusfigure is afbeeldings van bekende Middeleeuse persone wat as rolmodelle opgetree het. Die gewone aardse werklikheid is nie ontken 
nie, aangesien daaglikse bedrywighede van die Middeleeuse gemeenskap ook in die versiering van die gebou opgeneem is. Een van die belangrikste redes vir die inkorporasie van soveel simboliek in die uitbeeldings van Bybelse gegewens was veral om die ongeletterde mense te onderlê in die heilsfeite. Die pionier van die Gotiese boustyl in katedrale, die ab Suger, was van mening dat "man may rise to the contemplation of the divine through the senses" (Clark, 1975:60). Volgens hom kan die mens alleen Absolute Skoonheid (wat met God gelykgestel word) verstaan deur die effek van kosbare en mooi dinge op die sintuie: "the dull mind rises to truth through that which is material" (p. 50).

In aansluiting hierby sou 'n mens kon sê dat Cloete in die digbundel Driepas die skepping en alles wat deel uitmaak van die mens se bestaan op aarde 'prospekteer' sonder om die waarde wat kuns in die oordra van geestelike waarhede kan hê, te minag. Die bekende aardse is uitgebeeld om uiteindelik die hemelse voor te stel. Dit wat Rutherford (1987:438) van katedrale sê, is dus ook op Driepas van toepassing: "For in the cathedral at least, if not in the world outside, the perfect medieval marriage of the spiritual and the temporal worlds was celebrated at every opportunity."

\section{Cloete se gefassineerdheid met vorm: tektologie}

Dit is egter nie maklik om hierdie twee wêrelde poëties te jukstaponeer nie. Vir Cloete lê "die probleem met die maak van 'n bundel ... op twee vlakke. Die een is seleksie - wat hoort by wat, want gedigte maak families - en dan by rangskikking. Ek glo nie daaraan dat jy 'n bundel uitgee soos 'n hond kleintjies kry, 'n werpsel nie. Jy moet 'n familie van gedigte maak" (vgl. Krüger, 1990:11).

Cloete se gefassineerdheid met vorm is naspeurbaar in al sy kritiese en kreatiewe tekste. Hy (1987:45) sien komposisie hoofsaaklik as die samesmelting van "taalmanifestasies" soos betekenis, klank en ritme, met "konsepsionele manifestasies" soos tyd en ruimte: "Al hierdie eenhede, 'units', vorm saam 'n eenheid, 'unity"'. Soos boustene pas die een eenheid uitbreidend op die volgende, om uiteindelik te lei tot 'n nuwe saamgestelde struktuur. Cloete et al. (1985b:142) verduidelik sy begrip van tektoniek dan soos volg: "So kan ons van elke onderskeibare onderdeel wys hoe die totale gedig opgebou word deur elemente van klein na groot. Woorde is opbou-elemente in die gedig." Myns insiens word tektoniek by Cloete dikwels eerder 'tektologie', wat in The Concise Oxford Dictionary (Fowler \& Fowler) verduidelik word as "Structural morphology, i.e. that which treats an organism as composed of organic individuals". 
'n Voorbeeld hiervan is "Pyura" (p. 79) uit Angelliera, waarin duidelik gesien word hoe die klein rooi-aasorganisme die hele aardbol ("kontinent", "pooltrillinge") in homself opneem. Terselfdertyd kan weer geredeneer word dat die hele aarde vir die klein seediertjie se onthalwe bestaan. In "gehuldig in klip" (p. 80) uit Allotroop word die gedig ikonies die "monument" deurdat die versreëllengtes al hoe korter word om die voete van die beeld voor te stel. Die 'saamboerdery' van die Grote en die kleine blyk ook uit die tektologie van "koöperasie" (p. 103) uit Idiolek. 'n Duidelike tektologiese draai word in "Per slot van rekening" (Jukstaposisie, p. 51) se middelste strofe teweeggebring deur die klem in die eerste twee strofes te laat val op die grootsheid van die skepping en die mens se onvermoë om dit alles te 'bevat'. In die middelste strofe raak hierdie twee ongelykes min of meer ewewigtig wanneer die spreker besef dat hy tóg die aarde in homself opgeneem het in die vorm van vitamine en minerale, maar dit weer uitgeskei het. Daarna word hy weer heerser, wat die skepping verspil. Die spreker stel dat daar "hiate" in hom was wat 'n verskraalde lewenskwaliteit tot gevolg gehad het. In Driepas word hierdie leemte gevul deur die poësie wanneer die spinnekop as beeld van die digter selfs die sterflikheid met haar web óórkom: "Sy heg haar vastrapplek déúr die hiaat / ... en sy bind / haar patroon óm die openinge wat sy laat" ("XIII Arachne se leegte"; Driepas, p. 185).

"Patroon" word dus in die digkuns van Cloete meer as tektoniek. Dit is 'n middel om die onbevatlike mee vas te vat; 'n geweefde strik waardeur dié Een wat "in die miniskule ad infinitum / ontsnap" ("3. kleinduimpiery", p. 147) voorgekeer kan word; 'n gekarteerde roete om die "onoorsigtelike totaal" ("1 snuffel", p. 176) van die gedig, bundel en oeuvre - ja, van die léwe - "ineen ineens" ("1. die gedig is 'n refleks", p. 34) onder oë te kry.

Ook uit Met die aarde praat word dit duidelik dat dit deur middel van tektologie is wat Cloete daarin slaag om al die "dekorasies" van die digkuns só saam te stel dat dit die gedig "se lieflike klank help bepaal" ("Moskou 2", p. 7). Dit doen hy op so 'n vemuftige wyse dat die intellektuele ordening die toevallige leser selfs ongemerk verbygaan en tog die 'boodskap' van die gedig ondersteun: "Niemand wat die klok hoor, besef / hoe haar rok met sienmotiewe in reliëf / gedekoreer is nie." Gouws (1993:8) maak die leser daarop attent wanneer hy sê: "In die gedigte in die bundel word die aandag derhalwe skerp gefokus op die vorm, die komposisie of die tektoniek."

Die gedig "Insinjes" (32), ook in Met die aarde praat, "sinjaleer iets van die mooiste siermotiewe van God se skepping" (Gouws, 1993:8), soos dit in die reëlmatige heksagoniese vorm van die "sneeuvlok se patroon" vir die mens duidelik word. Uiteindelik word dit in "Entelegie" (p. 54) duidelik dat die 
tektoniese middele waarmee die digter werk eintlik ook maar aan God behoort. Dit waarmee Hy 'gevang' kan word, is by Hóm afgekyk, sodat Hy wéér eens (ad infinitum) 'ontsnap'. So word die "grootmeneer" ("Spinnekop", p. 55) van die web en weefsel die Groot Digter (vergelyk "God die digter" uit Driepas, p. 49); word Hy selfs méér as sy studente: "kul hy die taks van alle teo- en entomoloë" - én 'poëtoloë'!

Die (Goddelike) waarde wat Cloete aan vorm heg, word dus duidelik in sy hele oeuvre vergestalt. Die digterlike talent waarvan hy (vgl. Coetzee, 1983:13) praat, sorg dat hierdie vormgewing ook onbewus geskied, maar uiteindelik werk bewuste én onbewuste betrokkenheid van die logos saam tot wat Gouws (1986:25) "die daarstelling van 'n artefaktiële komposisie" noem. By die doelbewuste oprigting van 'n Goddelike woning sou Cloete dus vir seker ook buitengewone aandag aan die tektoniek wou verleen; in só 'n mate dat dit argitektuur word. Van Cloete se poësie sê Malan (1984:10): "Die mens verower sy plek in die kosmos deur middel van bousels." Met hierdie feit moet daar by 'n studie van Driepas rekening gehou word, asook met die spesifieke struktuur wat Cloete met Driepas beplan het: "Toe het ek gedink, nou goed, máák 'n katedraal waarin jy dan nou hier op aarde begin en dan bo eindig" (vgl. Krüger, 1990:11).

\section{Driepas en die Chartres-katedraal}

In 'n telefoongesprek het Cloete genoem dat hy in 1950 'n boek in Amsterdam gekoop het wat tydens die samestelling van die bundel Driepas sy gedagtes gerig het. Die gepaste titel vir die boek, Gedachten in steen, dui op dit wat hy met sy digterlike katedraal wou bereik. Die konsep van 'n katedraal het hom dus reeds in die vroeë vyftigerjare geboei en die ryke simboliek daarvan het hom sy lewe lank sodanig bygebly dat hy dit vier dekades later gebruik vir die konstruk van 'n bundel. Ook ander "besondere klipstrukture met religieuse assosiasies wat dateer uit prehistoriese tye" (Pretorius, 1984:86) is in vroeëre poësie opgeneem, soos dit blyk uit die titel van "Carcassonne en Karnak" uit Jukstaposisie (p. 100).

In die strewe om 'n digterlike katedraal te bou, is Cloete vooruitgeloop (en bes moontlik geïnspireer) deur Rainer Maria Rilke, wat in 1907 sy bekende 'Katedraal-siklus' publiseer. Wolf (1978:34) is van mening dat Rilke die katedraal van Chartres beskryf het. Aangesien daar in die sesde gedig (p. 187) van die afdeling "3. STOKKIESDRAAI" in Driepas 'n verwysing is na die Chartres-katedraal, kan die aanname gemaak word dat Cloete ook hierdie katedraal as model gebruik het in sy samestelling van Driepas. Hierdie aanname is regverdigbaar, veral as in ag geneem word dat die bundel as geheel 
duidelike strukturele ooreenkomste met genoemde katedraal vertoon, teenoor die vele ander Middeleeuse katedrale in Europa en elders wat na deeglike ondersoek nie dieselfde strukturele ooreenstemming met die bundel toon nie. (Kyk Van Jaarsveld [1993], vir 'n volledige 'prospektering' van die argitektuur van die Chartres-katedraal, soos dit in sy geheel van toepassing gemaak is op Driepas.) In hierdie lig is niks in die sanestelling van die bundel oorbodig nie, in teenstelling met die kritiek wat deurgaans gesê het dat daar in dié bundel oordaad is.

Die ordening van die bundel kom ooreen met die Middeleeuse begrip van orde, wat volgens Von Simson (1989:22) gegrond was op Augustinus se opvatting dat daar 'n goddelike verband is tussen musiek en argitektuur, want albei is op getalle gegrond. (Die verhouding musiek = argitektuur en poësie $=$ argitektuur, word dus nou ook poësie = musiek, soos die vele verwysings na musiek en komponiste in gedigte in Driepas bewys.) Die ontwerp van die katedrale is volgens die getalleleer van Augustinus beplan, soms selfs teen alle praktiese oorwegings in. Vanweë die kolossale omvang van die gebou, asook die wiskundig-berekende plasing van die argitektoniese stylmiddels, soos die aantal boë en vensters, kan die lywigheid van die digbundel en die oorvloed genommerde gedigte wat daarin voorkom, as goed beplan en betekenisvol beskou word. Die bundelkonstruksie vorm só 'n letterlike katedraal, wat "wyskundig" ("XIII Arachne se leegte", p. 185) met die boumiddele van taal opgerig is.

Die digter se motivering vir die samestelling van die bundel kom merkwaardig ooreen met die ideaal van die argitekte van die katedrale. Katedrale is gebou in die vertroue dat "God's Essence would be made manifest in something they built from the materials found on the earth" (James, 1982: 85). Volgens James het hulle hierdie ideaal juis bereik deur die belangrikheid van getalle as struktuurmiddel. Hierdie ooreenkoms bewys kritici wat probleme gehad het met die omvang van die bundel, sowel as die enumerasietegniek wat daarin voorkom, as oppervlakkig in hulle omgang met Driepas. Hambidge (1990:2) het dit reg as sy sê: "Om 'n digbundel van hierdie opset te konstrueer - en al die genoemde temas te laat inspeel op mekaar - getuig nie net van 'n geweldige intellektuele dissipline nie, maar ook van kreatiwiteit."

Die uitleg van die Chartres-katedraal is 'n Middeleeuse argitektoniese gegewe, maar Cloete het dit as poëtiese reisiger of pelgrim nuut ontgin, om sodoende die struktuur van sy eie digterlike soeke na die wese van God te begelei. "In die overblijfselen van schilderwerk, beeldhouwwerk en architectuur," stel Van Goirle (1948:1) dit in 'n ander konteks, "leest hij de gedachten welke de mens 
vroeger bezielden, zijn leven beheersten en aan zijn bestaan een richting gaven".

Hierdie sake word deur Cloete op 'n geordende wyse in die bundel ondersoek. As digterspreker/gids verken, dokumenteer en verbeeld hy die argitektuur van die katedraal. Die leser benodig 'n gids om in die "onoorsigtelike totaal" ("I Snuffel", p. 176) van die bundelkatedraal rondgelei te word. Hy word dan deur die digterspreker "op loop" ("op loop", p. 33) geneem en bevind homself in elke afdeling van die bundel metafories geplaas en ruimtelik georiënteer ten opsigte van die fisiese uitleg van die katedraal.

Die Middeleeuse mens het die katedraal in ' $n$ bepaalde orde beleef. Daar was 'n sekere voorgeskrewe pas of gang - wat ook simbolies en argitektonies ondersteun is - wat die toegang en déúrloop van die katedraal betref; gevolglik was die ingang tot die katedraal altyd Wes. Op grond van die Middeleeuse ordekonsep van die uitleg van die katedraal sou aanvaar kon word dat die leser wat Driepas opneem en by die eerste afdeling begin lees, homself metafories gesproke as toeris voor die Wesfront van die katedraal bevind. Dit is slegs die poëtiese ooreenkomste tussen die bundel en die Wesfront van die katedraal wat in hierdie artikel ondersoek sal word.

\section{1 "Flehmengrimas"}

In sy beskrywing van die westelike front van die Chartres-katedraal, noem Hartt (1989:449) die drievoudige portaal "the splayed triple portal" (ons kursivering). Die woord "splayed", sê die Concise Oxford Dictionary, is 'n "surface making oblique angle with another, mouth stretched wide in grimace" (ons kursivering). Die "oblique" dui verder daarop dat die betrokke hoek, voorwerp of saak nie dieselfde lyn volg as die bestaande nie, maar enigermate daarvan afwyk. Vanweë die kontakpunt wat deur "splayed" en "grimace" tussen die katedraal en die afdelingstitel geskep word, kan die aanvangsposisie van die leser en begeleidende digterspreker ten opsigte van die struktuur van die bundel geverifieer word as ooreenkomstig die posisie reg voor die westelike front van die Chartres-katedraal.

"Flehmengrimas" is die enigste afdeling in die bundel waarin die paringspel van mens en dier in elke gedig voorkom. Binne die "lywige Driepas" waarvan Hambidge (1990:7) praat, kan hierdie afdeling as die 'lyf-igste' gesien word. 'n Mens sou dus kon redeneer dat "Flehmengrimas" effe los van die res staan en dat die tematiese ooreenkomste met die res van die bundel derhalwe meer verskuil is. Daar is in hierdie afdeling geen verwysing na God, of enige ooglopende verbande met Hom as Skepper van mens en dier nie. Die afdeling eksploiteer eerder die banaliteit van die verworde seksuele verhouding in 
gedigte soos "dorpie wes-transvaal" (p. 25: "die ds het die dr so het ek gehoor / by sy vrou in die bed vermoor"), "ons eeu se aphrodite" (p. 26: "sy't geslaap by die beste") en "Kreunsand" (p. 27: "hulle is eerder agter die bulle"). Verwysings na die buffel in die afdeling se motto en na paring in die natuur in gedigte soos "balts" (p. 13: "langnekswane / en pelikane / ... liefkoosss"), "the mating game" (p. 21: "dié speletjies / wat gespeel / word en wat in die speletjie / kopverloor teel") en "oordag" (p. 17: "'n tol 'n hygende blom vir 'n tierende by"), beskryf die seksuele op dierlike vlak. Die tuin speel hier, soos in Angelliera, 'n belangrike ondersteunende rol. Die jag(s)proses word in " 1 . konsert van die verliefdes", "2. piccolokonsert" en "3. klankkoïtus" vanuit die fauna op die musiek getransponeer. Dieselfde gebeur met die poësie, wanneer dit in "Zeus vandag" (p. 14) as fantoomgedaantes met (onder andere) 'n perdeby, krap en spinnekop gelyk gestel word. Die kort morele ondertone van "droom" (p. 15: "ons was te veel self"), "1. eskapade" (p. 16) en "2. balans" (p. 16) word oorskadu (en selfs versterk) deur die intens aardse en eksplisiete uitbeelding van die huwelikspassie.

Nêrens elders in die bundel word daar so direk en openlik met die skril erotiese omgegaan nie. In ander afdelings word verwysings na die seksuele versigtiger verbeeld, selfs verskans, en uitbeeldings van die naakte liggaamlike word met deemis as kunswerk binne die gedig behandel. Tog vorm die afdeling "Flehmengrimas" 'n onlosmaaklike deel van die bundel, net soos die drievoudige Wesportaal van die Chartres-katedraal eie daaraan is en - te oordeel volgens die algemene plasing van foto's van die Wesfront in bronne - selfs die bekendste en indrukwekkendste deel van die katedraal uitmaak. Cloete sê dat die erotiese gedigte in Driepas van die bestes in die bundel is (vgl. Krüger, 1990:11). Verder maak die uitbeeldings in die timpane van die Wesportaal van die katedraal dit vir die toeskouer wat nog net buite die gebou staan en daarna kyk reeds duidelik dat dit in hierdie katedraal gaan oor die verheerliking van Christus self. Hoewel die digterspreker in "Flehmengrimas" nog met sy voete plat op die aarde en nog deeglik in die wêreld staan, is die besef reeds daar dat hy hom binne die 'katedraal' van die bundel op 'heilige grond' gaan bevind. Die vele verwysings na die natuur in die beskrywing van die erotiese, bring alreeds God as Skepper ter sake. Hieruit volg dat God óók gesien moet word as die Skepper van die seksuele drif. Immers, "as mens weet dat die Here God is, kan jy alles wees - sensueel, ironies, speels, ernstig", sê Spies (1984:28) in 'n bespreking van Cloete se religieuse poësie. Gesien binne hierdie verband word dit duidelik uit die afdeling dat dit die mens as geskapene is wat hierdie goddelike gegewe binne skeppende verband positief kan gebruik en geniet, of dan negatief kan perverteer. 
Die geslagsdaad as skeppingsdaad word ook binne hierdie afdeling in verband gebring met die kunste; hier meer spesifiek die musiek en die poësie. Die titel van die bundel, Driepas (dans vir drie persone), word ook in die indeling van die gedigte in hierdie afdeling geillustreer, deurdat die gedigte in vyf duidelike ritmiese groepe van drie afgetel kan word:

i) In die eerste drie gedigte ("balts", p. 13, "Zeus vandag", p. 14 en "droom", p. 15) word die seksuele eenwording beskryf soos dit deur die res van die afdeling sal voorkom, naamlik in terme van die dierlike/natuur, die kunste en die menslike liefdesuiting.

ii) Hierna volg twee genommerde gedigte ("l. eskapade", p. 16 en "2. balans", p. 16) wat 'n Christelik/morele perspektief gee op die uitlewing van die menslike seksualiteit, met daaruitvolgend 'n ongenommerde gedig ("oordag") wat die vrye uitlewing van menslike seksualiteit ("soos die diere") binne die "bedwang" van die huweliksverbondenheid weergee.

iii) Die patroon van twee genommerde en een logies opvolgende ongenommerde gedig word voortgesit. Eers word die liggaamlike eenwording beskryf (" 1 . ek alleen met jou", p. 18 en " 2 . ik ben met $u$ alleen o venus", p. 19) en dan volg die logiese uitvloeisel van hierdie koppeling, naamlik voortplanting ("the mating game", p. 20). Net soos die mens homself voortplant sodra hy 'n permanente liefdesverhouding aangeknoop het, net so produseer die kunstenaar kunswerke vanuit sy verbondenheid met die kuns.

iv) Drie genommerde gedigte, wat almal die seksuele en die kuns (veral musiek) met mekaar in verband bring, volg dan: "1. konsert van die verliefdes" (p. 22), "2. piccolokonsert" (p. 23) en "3. klankkoïtus" (p. 24).

v) Die laaste groep van drie gedigte ("dorpie wes-transvaal", p. 25, "ons eeu se aphrodite", p. 26 en "Kreunsand", p. 27) wys dan op die mens se bederwende aanwending van hierdie skeppende gawe.

Net soos die besoeker aan die Chartres-katedraal reeds buite die gebou weet dat dit om Christus gaan, net so weet die leser van hierdie afdeling dat dit in hierdie bundel veral gaan om dié liefdesdans - die mens (a) as geroepe kunstenaar, wat (b) 'n permanente verhouding met God (as indirekte Skepper van die kunste) aangegaan het en (c) wat nou aan sy eie kunslewering binne hierdie verstrengeldheid gestalte gee. 


\section{2 "Deelgenote"}

Waar die eerste afdeling verwagting by die 'toeris' geskep het, begin die digterspreker in die afdeling "Deelgenote" om die koninklike Wesportaal van die Chartres-katedraal poëties te beskryf. Daar is reeds gemeld dat die ingang tot die katedraal bestaan uit drie deure. Bokant elke deur is tonele uit die lewe van Christus, elkeen sentraal binne 'n boog. Elke boog bestaan op sy beurt weer uit drie dieperwordende vlakke, of voussures. Op elkeen van hierdie vlakke is ses uitbeeldings wat vanaf die basis van die boë as spieëlbeelde weerskante van Christus na mekaar toe beweeg, met 'n sleuteluitbeelding of sluitsteen op die hoogste punt van die boog, waar die uitbeeldings mekaar ontmoet. Verskeie sake word uitgebeeld. Rondom die sentrale boog met Christus as Oorwinnaar op sy troon verskyn diegene wat tydens sy aardse wandel die naaste aan Hom gelewe het en sy pad intiem saam met Hom geloop het, naamlik die twaalf apostels. Ook die wesens wat Hom ewiglik bedien en gedien het, naamlik die engele, word op die timpaan uitgebeeld. Op die drieledige boë weerskante word ander sake uitgebeeld wat in diens van Christus staan, soos die sterrebeelde, die filosofie en wetenskap, die beroemde staatsfigure van Bybelse en ander tye. Ook die verskillende seisoene en uitbeeldings van lower word uitgebeeld. Belangriker vir die doel van hierdie studie is die uitbeelding van die sewe vrye kunste.

Dieselfde motiewe word in die tweede afdeling van Driepas, "Deelgenote", gevind. Die eerste drie gedigte verteenwoordig die aansig van die digterlike 'katedraal'. Hierdie eerste drie gedigte is die drie deure waardeur die afdeling (selfs die bundel) binnegegaan moet word. Hier verteenwoordig "duo" (p. 31) die hoofdeur, wat insig bring in die dualiteit wat vir die saligheid nodig is, naamlik volledig mens- en kunstenaarwees wat slegs moontlik is in afhanklike verbondenheid aan die Skeppergod. In die ander twee gedigte word dit duidelik dat die digter ook dinge het wat vir hom belangrik is en 'n durende invloed op sy lewe uitoefen. Hierdie gedigte kom tematies ooreen met die drie reliëfwerke in die boë bokant die Chartres-katedraal se deure.

Die sentrale uitbeelding van Christus as Oorwinnaar is omring met apostels (mense), en met engele, wat dui op die dualiteit van Christus se wese, naamlik waaragtige God en waaragtige mens. In albei hierdie hoedanighede het Christus bystand of deelgenote nodig. Cloete identifiseer homself (as digter wat "rommel" in die "hoos" van 'n gedig laat sluit) dan hier met Christus: "het 'n veeg / weg van wat planete komete en sonne beweeg" ("2. moer"). In die gedig "Deelgenoot" (p. 34) sonder hy die poësie uit as dié deelgenoot in die uitlewing van sy roeping op aarde. Hierdie drieledige gedig wat opgedra is an die gedig 
en die digterlike proses, verteenwoordig die drie dieperwordende halfsirkels of voussures binne die drie boë van die katedraal.

Op elke halfsirkel langs die Christus-uitbeeldings verskyn ses van sy 'deelgenote' aan weerskante. Eweneens volg daar nou in hierdie afdeling van die bundel ses genommerde gedigte waarin die mens en God se kunswerke besing word. Hiermee sê die digterspreker dat hy nie sonder hierdie skoonheid in sy lewe produktief wil of kan lewe nie. Volgens Stoddard (1987:13) word die strukturele argitektuur van die Wesfront van die Chartres-katedraal ondersteun deur die lyne wat die figure wat uitgebeeld word, volg. In hierdie afdeling van die bundel is daar uitbeeldings van bekende kunstenaarsfigure. Die komposisie van die bundel word sodoende ondersteun, want dit word hierdeur weer eens duidelik dat die skilder- en beeldhoukuns, die musiek en die natuur telkens as deelgenote in Cloete se groot deelgenoot, die poësie, sal voorkom.

Daarna volg die ses filosofies gefundeerde deelgenote aan die ander kant in die gedig "oorloop" (p. 43), te wete die groot en ewige teenstellings wat die lewe litmaak en waarmee die denkende digter homself altyd poëties sal vermoei. Net soos die katedrale altyd die vice en die virtue as ineengestrengelde persona verbeeld het, net so vind ' $n$ mens dit in hierdie gedig in jukstaposisie: geluk en ongeluk, genot en pyn, hoop en wanhoop, kosbaarste poësie en parodie, vreugde en droefheid, uiterste skoonheid en intellek en monster en idioot - daarmee saam selfs die goeie en die bose in die mens.

Die sluitsteen wat hierdie digterlike halfboog afrond, is die gedig "uitpraat" (p. 45), waarin die digter homself in sy gebrokenheid geheel en al toewy aan die sentrale Christusfiguur.

\section{3 "God is digter"}

Die Wesfront van die Chartres-katedraal is verder bekend vir die venstergroeperings wat bokant die deure voorkom - groeperings wat uit drie lansetvormige vensters en dan veral ook die sogenaamde roosvenster bestaan. In die afdeling "God is digter" is daar ook duidelike strukturele ooreenkomste met hierdie vensters. Aan die begin van hierdie afdeling verskyn daar drie ongenommerde gedigte, wat tematies ooreenstem met die drie lansetvensters van die katedraal. Die middelste venster is groter as die twee syvensters en dra dus die meeste klem. Een van die gewone funksies van vensters is om lig op die binnekant van 'n gebou te laat val. Die lig wat deur die venster kom, beïnvloed dus die waarneembaarheid van die gebou se binnekant. In die katedraal bestaan die vensters egter uit gekleurde glas, wat wel die lig deurlaat, maar die kwaliteit daarvan verander om sodoende 'n sekere atmosfeer te skep. 
Op dieselfde wyse is die eerste drie gedigte van hierdie afdeling van die bundel 'vensters' op die inhoud van die afdeling en die bundel as 'n geheel. Dit kleur die hele inhoud met die siening dat God self digter is en impliseer dat $\mathrm{Hy}$ verantwoordelik is vir die 'inkarnasie' van die digter se kunsskepping.

Hierna volg twee gedigte wat as 'syvensters' van hierdie hoofsiening beskou kan word. Aan dic een kant wys "paddastoeltuin" (p. 50) op die bederwende en vernietigende invloed wat die mens op die skepping het wanneer hy met sy eie wil en beperkte menslike kennis met die skepping omgaan. Deur ongehoorsaamheid ("Lot se vrou"), afgodery ("Oosterse tempels"), wêreldsgesindheid ("in die mode wil wees") en onverantwoordelike rentmeesterskap ("fisika se pofatoom") kom daar dissonante momente in die 'poësie van God'. Let daarop dat die "grashoed op die Zulu se kop" nie hinder nie, aangesien dit 'n paradyslike toestand van die ongekunstelde mens is wat die skepping op 'n natuurlike manier vir sy behoeftes (nie ydelheid nie) aanwend, want die hoed is van gras gemaak.

Aan die ander kant is daar die vloeiende, ongehinderde gang in die poëtiese ritme van "Wolk in die wind" (p. 51). Waar die mens se pogings in die teken van die eindigheid staan, bly God voortskep. Dié gedagte van God se onblusbare skeppingsdrif kom weer in die bundel voor, byvoorbeeld in "I Snuffel" (p. 176) en "IV Sunday blues" (p. 177).

Net soos die hoofvenster aan die Wesfront van die Chartres-katedraal feitlik aan die roosvenster daarbo raak, net so verwys "God die digter" (p. 49) reeds na "die rooswolk" wat baie "liriek" bevat. Logieserwys volg daar dan twaalf genommerde gedigte, wat struktureel ooreenkom met die veelvuldige gebruik van die getal twaalf in die roosvenster van die katedraal. Roosvensters in katedrale simboliseer in die eerste plek die mens se hoogste aspirasies: "to know God's order, to become at one with Him, and ultimately to become cocreators with the Creator" (Cowen, 1979:10). Die venster is ook simbolies van die skepping en die natuur se sikliese herlewende vermoë.

Wanneer die digter dan in sy digterlike soeke na kennis van en eenwording met God die natuur verdig, is hy medeskepper daarvan. Hoewel die twaalf gedigte almal as "Landskappe" beskryf word, bevat dit, eie aan die liriek, ook die verwoording van persoonlike gevoelens van die digterspreker. Elkeen van die tonele word gekleur deur die 'loodglas' van sy eie verbeelding. So lyk die Kamdeboo vir hom net soos "ingesakte berge van bo". In die Karooberge sien hy ooreenkomste met die vroulike bors en in die Swartberge sien hy afbeeldings van rustende menslike figure. Die ooreenkomste met mense gaan dan oor in ' $n$ vereenselwiging met die natuur in 'n beskrywing van maanlig in die 
Tsitsikamma en die berge in Kareedouw. Soos die motiewe in die siklus van die 'roosvenster' van gedigte mekaar tot in die helfte van die sirkel opvolg, bring dit die waamemer dan by die punt waar die digter sy verwondering uitspreek oor die grootsheid van die skepping in die tydsame afskilfering van die Bosveldse granietkop (p. 54).

In die Kango- en Sudwalagrotte word rotsformasies vergelyk met Gotiese katedrale. Die gedig, "7. Berg en grot" (p. 54), bevat ook een van die belangrikste sleutels tot die ontginning van die bundel. God, wat in hierdie afdeling ook as digter aangebied word, is volgens dié gedig "die argitek van katedrale". Deur Cloete se uitspraak dat hy 'n katedraal met die bundel wou bou hier te betrek, blyk dit sy oortuiging te wees dat God sélf déúr hom die bundel Driepas beplan en uitgevoer het.

Saam met hierdie besef volg dan die logiese lof aan God, soos dit in die Biedouwvallei óók deur graffiti (kyk "Rooi Kannetjie") tot uitdrukking kom: "God leef." Hennie Aucamp (1984:77) haal 'n gedig van Cees Nooteboom aan waarin graffiti aangehaal word wat sê: "God leeft en is gezond en leest nog zonder bril." Dit illustreer die onbewuste begeerte van die graffitiskrywer om die samelewing op 'n subversiewe wyse wakker te skud, tot die (h)erkenning van hulle eie kollektiewe en onderdrukte gedragsuitinge en begeertes. In Cloete se gedig is die graffiti dalk ook die moderne mens se inskripsie in die katedraalgrot van sy kollektiewe geheue of verlede. Net soos die oermense hulle grootste ervarings deur rotskuns in grotte uitgebeeld het, net so word die ongerepte rotswande van die Biedouwvallei ontsier met ongevraagde inskripsies. Hierdie 'ontsiering' word egter vanweë die grootsheid van die graffiti-boodskap - wat deur alle mense heimlik en ontsettend gewéét word tot groot kunswerk getransformeer. Aucamp (1984:84) sê juis aangaande graffiti-inskripsies: "hulle kan die prikkels verskaf wat tot insig en openbaring lei waaruit opperkultuur kan ontstaan: letterkunde en kuns in al hul geledinge". In die 'katedraal' van die kollektiewe poëtiese ekspressie van die mens funksioneer Driepas dan ook as 'graffiti' wat wil sê: "God leef."

Die klippe in die Sederberge en die Namakwalandse blomme maak dit dan duidelik dat God die skepping beplan het om 'n "piekniek" en 'n "fees" te wees. Die mens kan daarvan vrylik geniet, soos dit ook elders in die bundel na vore kom, byvoorbeeld in "verlore seun" (p. 95) en "X. Hamster" (p. 182).

Die siklus is byna voltooi met die beskrywing van die kreunsand in die Noordwes-Kaap wanneer daar - soos in "2. Karooberge" (p. 52) - 'n vergelyking getref word tussen die vroulike liggaam en die natuur. Waar die vroeëre verwysings na "tet" en "stywe jong pram" 'n element van aardse genot 
gehad het (wat ook deur God aan die mens gegee is), word die ander sy van die funksie van die vroulike liggaam hier belig, naamlik die pyn en moeite waarmee sy haar kinders baar (volgens Gen. 3:16 ook deur God so bestem).

Hierdie rotasie van natuurindrukke eindig in 'n rusmoment met die twaalfde gedig, "misreën" (p. 56). Die altyd "na-denkende" ("IV Sunday blues", p. 177) digter hou hier op om sy "beroemde beseerde / gemoed" ("op loop", p. 33) te teister met vrae soos "wanneer waarvandaan / laat staan waarheen". In die natuur kom hy tot rus. Die getal twaalf simboliseer juis die perfekte eenwording tussen goddelike en aardse, en volgens Cirlot (1971:234) ook kosmiese orde en redding.

Die gedig "naturalis" (p. 57) verteenwoordig die sirkel wat die roosvenster van die katedraal omsluit. Die wielkode simboliseer groei en ontwikkeling en word deur die ritme en woordkeuse van die gedig ómskryf:

\author{
dat ons almal in die groot roteer \\ binne die voorlê saam \\ uiteindelik sal omgaan \\ in 'n onderons \\ onder- en bogronds \\ binne ' $\mathrm{n}$ bestendige veranderlike Naam.
}

Die groei wat hier plaasvind, is die "ander samestellings" waartoe die "rusteloos hervormende hand" van God hom in die hiernamaals gaan "verbrou" ("I Snuffel", p. 176). Tot hierdie aanvaarding van sy tydelikheid as deel van die skepping het sy eenwording met die natuur in 'n soort "panenteïsme" (Odendaal, 1993:8) hom gehelp. Hierdeur word die klawerkode - wat die eenheid van mens, natuur en God voorstel - duidelik omlyn.

Bokant die roosvenster van die Chartres-katedraal is daar 'n ry van sestien koningsfigure wat uit klip gekerf is en langs mekaar binne gepunte nisse staan. Hoewel Aubert (1959) van mening is dat hierdie figure eerder die aartsvaders en die profete uitbeeld, stem die meeste kenners tog saam dat hierdie figure die voorgangers of argetipes van Christus uitbeeld. Dit kan ook heiliges voorstel.

Die galery figure kom ooreen met die toneel wat in "Uitsluitsel" (p. 58) geskilder word: gepunte berge as agtergrond, met skraal, regop bome wat as figure bymekaar gesien word. Hulle is ook een met die klip waaruit hulle groei. Die figure op die katedraal is dié van heiliges, wat tot eer van die moeder Maria gekanoniseer is. Net so het die kiepersolle ontstaan uit 'n "moederlike peulsaad" en is hulle "eksklusief", wat die spreker uitgesluit laat voel. Dié 
kloof tussen mens en natuur is raar binne die milieu van die bundel en moet dus juis om daardie rede veelseggend wees. Nie alleen voel hierdie toeris homself uitgesluit by die aanskoue van die ry eendersdenkende (ge)heilig(d)es nie, maar dit lewer terselfdertyd kommentaar op Cloete se Calvinistiese geloofsbenadering, waarin daar vir die mens (dus ook die kunstenaar) geen verering mag wees nie. Net soos daar vir die mens binne die gedig geen plek is in hierdie stukkie natuur waaroor hy moet heers nie, net so was daar in die wêreldse sfeer geen plek vir Christus nie. Die digterdissipel het dus nou geen soeke na aardse verering nie, maar in nederigheid moet hy met sy "snuffelende asemhaal / vir Hom as gids 'n medewerker wees" ("I Snuffel", p. 176).

Uiteindelik is die nederige bewussyn van geroepenheid een van die hoofinsigte by die bestudering van hierdie eerste drie bundelafdelings (met hulle onpretensieuse tematiek en treffende strukturele ooreenkomste met die Wesfasade van die Chartres-katedraal).

\section{Slotsom}

Daar is reeds daarop gewys dat die Wesfasade die aansig is waarvoor die Chartres-katedraal bekend is. Aan die einde van die ontginning van die poëtiese beskrywing van slegs hierdie aansig alleen, kan die afleiding reeds gemaak word dat die insigte wat tot dusver aangaande die digter se posisie en taak binne die grootsheid van die skepping bekom is, ooreenstem met die sentimente waarvoor Cloete bekend is en dít wat hy met sy Driepas-katedraal wou bereik.

Die verdere parallelle met die struktuur van die katedraal maak van die bundel as geheel 'n religieuse ruimte. Hiervolgens funksioneer die afdeling "Rooi data" as toergids vir die verdere verkenning van die literêre katedraal. Uit hierdie afdeling word dit duidelik dat die mensdom nooit weer aan die gevolge van die sondeval kan ontkom nie. Daar moet dus gesoek word na versoening met God, nie net ter wille van die mens se eie redding nie, maar ook ter wille van die skepping. Hierdie soektog begin dan in alle erns in die volgende afdeling.

As deel van die Middeleeuse ordekonsep het godsdienstige prosessies en pelgrims die katedraal altyd kloksgewys deurloop. Wanneer die 'toeris' by die Driepas-katedraal in sy getransponeerde soeke na God se wese begin om antikloksgewys om die gebou te loop, dui dit reeds daarop dat hy God en sy werke op 'n onkonvensionele manier ondersoek: digterlik, eerder as teologies.

Binne die struktuur van die bundel vorm "Prospekteer I" saam met "Prospekteer II" die twee 'torings' van die 'katedraal'. Dit is die skagte 
waarbinne daar in gedigte soos "Reis na Namakwaland" gemyn gaan word op soek na God se wese in die natuur en die huwelik. As daar vervolgens om die suidelike toring geloop word, bereik die toeris die Suidportaal, wat saam met die Noordportaal die dwarssy van die kruisvorm waarin die katedraal gebou is, vorm. Die Suidportaal is toegewy aan die verheerliking van die sogenaamde heiliges en aan die laaste oordeel. So word die afdeling "Vreemde meriete" in die bundel gewy aan diegene wat volgens ons oordeel vanweë een of ander gebrek of sonde die oordeel van God op hulle behoort te haal en tog deur Hom hier in die lewe op verskillende maniere en met 'vreemde meriete' besonder begenadig word.

Die swewende balke buite om die Chartes-katedraal is aan die oostelike kant besonder indrukwekkend. Op sy poëtiese besigtigingstoer rondom die katedraal bevind die digterspreker hom juis nou met die afdeling "Duel" aan die 'Oostekant'. Die gevolgtrekking kan gemaak word dat een en twintig genommerde gedigte in die afdeling ooreenstem met die een en twintig strategies geplaaste balke wat rondom die apsis van die katedraal opgerig is om die struktuur van buite af te steun. Die inhoud van die gedigte in hierdie afdeling illustreer die sublimering van die mens se aggressie en veglus in sporten ander wedstryde en God se plek daarin: "That hand / that pulls the strong / down, and makes weak ones stand" ("XXI Daardie hand", p. 108).

Die digterlike soektog na 'n Verlosser om by die innerlike genesing en gevolglike Lewe (verteenwoordig deur die binneste kapelle van die katedraal) uit te kom, word ná die ondersoek van moord by mens en dier weer eens duidelik. Verdere eksplorasie lei tot die ontginning van die noordelike transep. Die noordelike portaal van die katedraal van Chartres bevat meer as sewehonderd figurante wat die wederkoms van Christus simboliseer. Ná die gesimboliseerde aardse stryd is daar behoefte aan 'n Vredevors wat sy volk kan uitlei uit die Groot Verdrukking. Net soos daar in die noordelike portaal afbeeldings is van priesters, profete en konings wat 'n reddende rol in die geskiedenis van Israel gespeel het, net so verskyn daar ook in die afdeling, "Duvelrieë", 'n "1. nuwe moses" (p. 118) en "2. nog 'n profeet" (p. 118) elkeen verteenwoordigend van ' $n$ ander gemeenskap in Suid-Afrika.

Iemand het moontlik met 'n kannetjie rooi spuitverf onthutsende inligting op die katedraalmuur geverf en so kom die digterlike toeris op pad na die tweede 'toring' af op 'graffiti' wat as radikale kunsvorm iets subversief wil sinjaleer. Die sleutel tot dit wat deur die rooi verfkannetjie 'geskreeu' word, is te vinde in die gelyknamige gedig, "rooi kannetjie" (p. 136). Die soektog na 'n verlosser word in hierdie afdeling op die spits gedryf met die besef van die onafwendbaarheid van die dood wat almal bedreig. Die enigste verweer wat die 
mens in hierdie stadium teen die dood kan hê, is om daaroor op die katedraal se muur te skryf. So word die kuns verlossend betrek.

Waar die mens geen blywende oplossing vir pyn en sin in dood kon vind nie, moet daar in die groot en onbevatlike heelal na God gesoek word, sodat die lewe minstens sinvol gelééf kan word. Hiervoor word daar nou in die afdeling "Prospekteer II" in die tweede skag 'geprospekteer'. Hierdie werkwyse kom struktureel ooreen met die noordelike toring van die Wesfront van die Chartreskatedraal. Binne hierdie afdeling kom die digterlike prospekteerder nie alleen tot die besef dat Gód die méns in sy verlorenheid opsoek nie, maar ook dat die verlossing wat vír hom bewerk is, effek behoort te hê op die lewe van die individu. Hy moet ook die binnekant van die katedraal gaan verken om sodoende uit te vind hoe daar vir hom binne sy persoonlike aardse bestaan Lewe bewerk is.

Katedrale is meestal in drie vlakke gebou, naamlik die grondvlak, triforium (of middelste vlak) en die klerestoriale (letterlik clear storey) of helder vlak - só genoem vanweë die groot vensters waaruit die muur op hierdie vlak bestaan. Die laaste afdeling in die bundel word gepas "Klawer" genoem, vanweë die drievoudige klawersimboliek wat in die inhoud van die gedigte te vinde is, naamlik (onder andere) die verstrengeldheid van God, mens en kuns. Die binnekant van die 'Klawerkatedraal' is ook verdeel in drie stygende vlakke. Die eerste hiervan dra die subtitel, "1. TRIGLOOP" en dui op 'n 'terugloop' deur die temas wat reeds in die bundel ondersoek is. In die afdeling " 2 . NOU EN DAN" word daar in die deur gestaan en kyk na die kontrasterende moderne samelewing buite en die antieke suidelike muur van die binnekant van die gebou - vandaar die titel van die afdeling. Die sestien gedigte is tematies ingedeel in vier groepe van vier gedigte elk en kom struktureel ooreen met die triforium van die Chartres-katedraal, aangesien die boë in die suidelike skipgedeelte op hierdie vlak ook ingedeel is in groepe van vier. Inhoudelik wil die gedigte in hierdie afdeling sê dat kuns wat God verheerlik selfs na die dood van die kunstenaar sal voortbestaan - net soos die ou katedrale. In die "3. STOKKIESDRAAl"-afdeling wil die toeris nog 'n bietjie sloer en stap weer van Oos na Wes deur die katedraal, terwyl sy oë noodwendig gelei word na die loodglasvensters van die klerestoriale vlak: ses duidelike pare plus sewe groot lansetvensters agter die altaar. Die verband met die dertien genommerde gedigte in hierdie afdeling is duidelik. Net soos die skenkers of medewerkers van die loodglasvensters saam met die groot geestelike waarhede in die vensters uitgebeeld is, net so vorm Cloete se dertien gedigte die duidelike elemente van sy poësie in Driepas: seks, sport, wetenskap, sinlike genot, die verband tussen emosie en kuns, die dood, politiek, filosofie, die onskone, die besef van God se 
genade, die skakel tussen die hemelse en die aardse, 'n verhouding met die Skepper, asook die kunste en persoonlike talent vir die digkuns.

Die heel laaste gedig in die bundel, "tuiskoms" (p. 191), kom ten slotte struktureel ooreen met die koepel van die katedraal: "hoe ek op die koepel woon van 'n wonder". Die "halfmaan rante" wat "van wes na oos golf" kom ooreen met die geribde koepels wat van Wes na Oos dwarsoor die lengte van die katedraal op mekaar volg. Net soos die koepels in die katedraal die teenwoordigheid van God in sy 'tempel' moet versinnebeeld, net so word die geologiese "wonder" van die digter se geboorteplek vir hom die bewys van 'n Goddelike bemoeienis met hom as mens en as digter.

Of die navorsers in hierdie studie "aan die speel" (Cloete, 1984a:19) gesit is, moet die leser maar self oordeel. Een ding bly seker: Cloete se jarelange bewondering vir die veelheid van die tipiese beelding in katedrale het in Driepas saamgesmelt met die wondere van God se skepping om 'n nuwe en eiesoortige tektologiese bydrae tot die Afrikaanse poësie te maak. Ten opsigte van die bekroonde Driepas is daar al gesê:

(Dit) is ten slotte 'n magistrale himne aan die skepping, met Skepper en skepsel heerlik aanwesig daarin. As bundel word dit gereken saam met die bestes in Afrikaans. Wat hier tot stand gebring is, is niks minder nie as ' $n$ katedraal in taal (Anon, 1990: 105).

\section{Bibliografie}

Anon. 1990. Literêr-aktueel. Tydskrif vir Letterkunde, 28 (4):105-106, Nov. Aubert, M. 1959. Gothic Cathedrals of France and Their Treasures. London : Kaye.

Aucamp, H. 1984. Woorde wat wond. Kaapstad : Tafelberg.

Cirlot, J.E. 1971. A Dictionary of Symbols. London : Routledge \& Kegan Paul.

Clark, K. 1975. Civilisation. Rugby : Jolly \& Barber.

Cloete, T.T. 1980. Angelliera. Kaapstad: Tafelberg.

Cloete, T.T. 1984a. Die dromende denke van die digter. In: SAVALkongresreferate IV. Wits/Potchefstroom. pp. 1-20.

Cloete, T.T. 1984b. Jukstaposisie. Kaapstad: Tafelberg.

Cloete, T.T. 1985a. Allotroop. Kaapstad : Tafelberg.

Cloete, T.T. et al. 1985. Gids by die Literatuurstudie. Pretoria : HAUMLiterêr.

Cloete, T.T. 1986. Idiolek. Kaapstad : Tafelberg.

Cloete, T.T. 1987. Hoe om 'n gedig te ontleed. Pretoria : Academica.

Cloete, T.T. 1989. Driepas. Kaapstad : Tafelberg. 
Cloete, T.T. 1992. Met die aarde praat. Kaapstad : Tafelberg.

Coetzee, J. 1983. Die ingewing sóék jou ... nie jy vir hom ... Die Vaderland: 13, Mei 18.

Cowen, P. 1979. Rose Windows. London: Thames \& Hudson.

Fowler, H.W. \& Fowler, F.G. (eds.) The Concise Oxford Dictionary. Oxford : Clarendon Press.

Gouws, T. 1986. Die komposisionele spel in die poësie - ' $n$ verkenning van Antile Krog se "Otters in bronslaai". Potchefstroom : PUCHO. (Verhandeling - M.A.)

Gouws, T. 1993. T.T. Cloete praat weer eens saam met die grotes. Beeld: 8 , Feb. 8.

Hambridge, J. 1990. Lywige Driepas sleur mee. Die Transvaler: 7, Feb. 13. Hartt, F. 1989. Art. New York : Harry N. Abrams.

James, J. 1982. Chartres: The Masons Who Built a Legend. London : Routledge \& Kegan Paul.

Krüger, E. 1990. Die man het 'n KATEDRAAL gebou in 'n jaar. Beeld: 11, Feb. 10.

Malan, C. 1984. Die fyn essensie van 'stukkies mens en wêreld' in Jukstaposisie. Ensovoort, 4 (1):10-11, Mei.

Odendaal, B.J. 1993. Via alruin en seks tot God: die eiesoortige mistiek in die poësie van T.T. Cloete. Literator, 14(2):1-23, Augustus.

Pretorius, R. 1984. Skouspel en Carcasonne - die "klankdenke" in Jukstaposisie. In: Viljoen, H., Steenberg, D.H., Jooste, E. \& Gräbe, 1. (reds.) In teen die groot vergeet. Potchefstroom : Potchefstroomse Universiteit vir CHO. pp. 79-92.

Rutherford, E. 1987. Sarum. Suffolk : Richard Clay.

Spies, L. 1984. Geloof en gedig in die Afrikaanse poësie van Sewentig. Ensovoort, 4 (1):25-28, Mei.

Stoddard, W.S. 1987. Sculptors of the West Portals of Chartres Cathedral: Their Origins in Romanesque and Their Role in Chartrain Sculpture: Including the West. New York : Norton.

Van Goirle, C. 1948. Inleiding. In: Coppen, M. Gedachten in steen. Amsterdam : Elsevier. pp. 1-8.

Van Jaarsveld, A.E. 1993. Driepas (T.T. Cloete)-die digter as dissipel; die taal as katedraal. Mmabatho : Universiteit van Bophuthatswana. (Proefskrif - D.Litt.)

Von Simson, O.G. 1989. The Gothic Cathedral: Origins of Gothic Architecture and the Medieval Concept of Order. New York: Pantheon Books. 
Wolf, E.M. 1978. Stone into Poetry: The Cathedral Cycle in Rainer Maria Rilke's Neue Gedichte. Bonn : Bouvier. 